\title{
PENGELOLAAN DAN PEMANFAATAN SUMBER BELAJAR DI SEKOLAH TINGGI PARIWISATA AMPTA YOGYAKARTA
}

\author{
Adi Hidayat, Abdul Gafur \\ Sekolah Tinggi Pariwisata AMPTA Yogyakarta, Universitas Negeri Yogyakarta \\ addi_ada@yahoo.fr, agafur68@gmail.com
}

\begin{abstract}
Abstrak
Penelitian ini bertujuan untuk mengetahui gambaran secara empiris mengenai pengelolaan dan pemanfaatan sumber belajar di STP AMPTA Yogyakarta. Jenis penelitian ini adalah deskriptif dengan menggunakan pendekatan kualitatif. Subyek penelitian terdiri atas ketua, pembantu ketua, ketua jurusan, kepala UPT, kepala bagian pendidikan dan pengajaran, dosen, dan mahasiswa. Data dikumpulkan menggunakan metode observasi, pengkajian dokumen, dan wawancara. Sedangkan instrumen yang digunakan adalah lembar observasi, lembar pengkajian dokumen dan pedoman wawancara. Keabsahan data diperoleh melalui perpanjangan waktu penelitian, pengamatan intensif dan trianggulasi. Selanjutnya analisis data dilakukan dengan mereduksi, menyajikan dan memverifikasi data. Hasil penelitian menunjukkan bahwa (1) pengelolaan sumber belajar mencakup perencanaan, pengorganisasian, pengkoordinasian dan pengawasan, (a) bentuk perencanaannya berupa Renstra, RIP, ROT, (b) pengorganisasian sumber belajar belum terbentuk, (c) pengkoordinasian sumber belajar dilakukan oleh masing-masing ketua jurusan, (d) pengawasan sumber belajar menjadi tanggungjawab ketua jurusan; (2) pemanfaatan sumber belajar mencakup empat dimensi yaitu: (a) sumber belajar yang tersedia sudah dimanfaatkan untuk pembelajaran, (b) difusi inovasi dilakukan melalui saluran internal dan eksternal, (c) implementasi dan pelembagaan sumber belajar dilakukan melalui mekanisme workshop, pelatihan dan sosialisasi, (d) kebijakan dan regulasi sumber belajar belum secara spesifik menunjuk pada pengelolaan dan pemanfaatan sumber belajar.
\end{abstract}

Kata kunci: sumber belajar, pengelolaan, pemanfaatan

\section{MANAGEMENT AND UTILIZATION OF LEARNING RESOURCES IN THE COLLEGE OF TOURISM AMPTA YOGYAKARTA}

\author{
Adi Hidayat, Abdul Gafur \\ Sekolah Tinggi Pariwisata AMPTA Yogyakarta, Universitas Negeri Yogyakarta \\ addi_ada@yahoo.fr, agafur68@gmail.com
}

\begin{abstract}
This study aims to reveal the management and utilization of learning resources in the College of Tourism AMPTA Yogyakarta. This study employed the descriptive method. The subjects of the research were the head of STP AMPTA Yogyakarta, the head of departments, the head of academic affair, lecturers and students. The instruments of the data collection were observation sheet, document analysis sheet, and interview guide. The data were collected through interviews, document analysis, and observations. The results of the study show the following: (1) Learning resources management consists of planning, organizing, coordinating and supervising. (a) In term of planning, the planning is in the forms of strategic planning, RIP, and ROT, (b) in term of organizing, organization of learning resources are less integrated as consequence of absence of special unit in learning resource, (c) in term of coordinating, coordination of learning resources is conducted by the department head, (d) in term of supervising, supervision of learning resources is the responsibility of the department head. (2) Learning resources utilization has four dimensions as follow: (a) learning resources are already used for teaching and learning process, (b) diffusion of innovation is done through internal and external channels, (c) implementation and institutionalization is done through workshop, training and socialization mecanisme, (d) policies and regulations of learning resources is not specifically pointed to management and utilization of learning resources.
\end{abstract}

Keywords: learning resources, management, utilization 


\section{Pendahuluan}

Pembelajaran merupakan suatu proses interaksi antara mahasiswa dengan dosen dan sumber belajar pada suatu lingkungan belajar (Undang-Undang, Nomor 12, 2012). Dalam Undang-Undang (UU) tentang pendidikan tinggi tersebut terdapat empat komponen yang saling terkait yaitu, peserta didik (mahasiswa), pendidik (dosen), sumber belajar dan lingkungan belajar. Paradigma pendidikan lama menempatkan pendidik sebagai komponen terpenting dalam pembelajaran dan menempatkan peserta didik sebagai objek didik dan cenderung bersifat pasif. Paradigma tersebut berimplikasi langsung pada minimalnya peran peserta didik dalam eksplorasi dan eksploitasi pengetahuan dan ilmu. Pada kondisi tersebut pendidik menjadi satu-satunya sumber belajar atau setidaknya menjadi sumber belajar paling dominan dalam proses pembelajaran.

Sejalan dengan laju perkembangan teknologi informasi, sumber belajar menjadi tidak terbatas pada pendidik, menurut Betrus dalam Januszweski (2008, p.213) menyebutkan bahwa "the term resources is understood to include the tools, materials, devices, settings, and people that learners interact with to facilitate learning and improve performance. Definisi tersebut secara spesifik menyebutkan bahwa sumber belajar mencakup perkakas, bahan, alat, lingkungan dan orang yang digunakan untuk memfasilitasi dan meningkatkan kinerja pebelajar. Pendapat tersebut sejalan dengan AECT yang menyebutkan kategori sumber belajar yang yang terdiri atas pesan, orang, bahan, alat, teknik dan lingkungan (1977, pp.8-9). Dengan demikian pendidik (orang) adalah bagian dari sumber belajar.

Pada era ini, peserta didik dapat memiliki akses yang sangat luas dalam pemanfaatan sumber belajar. Sehingga pendidik tidak lagi menjadi satu-satunya sumber belajar. Paradigma baru yang berkembang kemudian adalah pembelajaran yang berpusat pada peserta didik atau lebih dikenal dengan istilah student centered.
Dalam paradigma baru tersebut peserta didik diposisikan menjadi subjek dalam eksplorasi dan eksploitasi ilmu dan pengetahuan. Hal tersebut dimungkinkan karena akses terhadap sumber belajar dapat dilakukan dalam berbagai kesempatan baik melalui pendidik sebagai fasilitator, mediator, dan narasumber, maupun melalui media-media yang terkorelasi dengan ilmu dan pengetahuan yang sedang dipelajari secara mandiri.

Paradigma baru tersebut selain menempatkan peserta didik sebagai subjek didik juga menempatkan sumber belajar sebagai bahan kajian yang memiliki peranan penting dalam pembelajaran. Oleh karena itu, perlu pengkajian mendalam terkait dengan pengelolaan dan pemanfaatan sumber belajar sehingga dapat diketahui derajat kontribusinya dalam peningkatan mutu pembelajaran. Lebih lanjut, indikasi peningkatan mutu pembelajaran dapat digunakan sebagai salah satu tolok ukur peningkatan mutu pendidikan secara umum.

Pembelajaran akan optimal jika didukung dengan sumber belajar yang memadahi dan sesuai dengan kebutuhan serta karakteristik pendidikan pada satuan pendidikan. Hal ini ditegaskan dalam Peraturan Pemerintah Republik Indonesia No. 19 tahun 2005 tentang Standar Nasional Pendidikan mengenai sarana dan prasarana pendidikan pasal 42 ayat 1 bahwa setiap satuan pendidikan wajib memiliki sarana yang meliputi perabot, peralatan pendidikan, media pendidikan, buku dan sumber belajar lainnya, bahan habis pakai, serta perlengkapan lain yang diperlukan untuk menunjang proses pembelajaran yang teratur dan berkelanjutan. Lebih lanjut pada pasal 43 ayat 6 disebutkan bahwa standar sumber belajar untuk setiap satuan pendidikan dinyatakan dalam rasio jumlah sumber belajar terhadap peserta didik sesuai dengan jenis sumber belajar dan karakteristik satuan pendidikan. Oleh karena itu, pengadaan sumber belajar harus melalui penelaahan dan analisis kebutuhan terlebih dulu. Dengan 
demikian, sumber belajar yang tersedia akan termanfaatkan secara efektif dan tepat sasaran.

Berdasarkan beberapa pernyataan yang termaktub dalam UU tersebut nampak secara eksplisit bahwa kedudukan sumber belajar sebagai komponen penunjang keberhasilan pembelajaran menjadi sebuah keniscayaan. Sekolah Tinggi Pariwisata (STP) AMPTA sebagai salah satu lembaga pendidikan tinggi yang menyelenggarakan pendidikan berwawasan pariwisata, yang mencakup beberapa jurusan yaitu; Perhotelan, Administrasi Hotel, Usaha Jasa Wisata, Manajemen Bisnis Perjalanan dan Hospitality, memiliki karakteristik pendidikan yang khas dan spesifik. Oleh karena itu, sumber belajar yang digunakan pun harus memiliki karakteristik yang khas pula.

Kekhasan sumber belajar yang dimaksud adalah sumber belajar yang memiliki relevansi dengan keilmuan dan keahlian dalam bidang pariwisata. Hal ini sesuai dengan UU Tentang Pendidikan Tinggi Pasal 41 ayat 1, bahwa sumber belajar pada lingkungan pendidikan tinggi wajib disediakan, difasilitasi, atau dimiliki oleh perguruan tinggi sesuai dengan program studi yang dikembangkan. Berdasarkan amatan peneliti, sumber belajar yang tersedia di STP AMPTA sudah cukup beragam dan khas, antara lain ruang kelas, perpustakaan, laboratorium bahasa, laboratorium bar and restaurant, laboratorium kitchen and pastry, laboratorium house keeping, laboratorium reception, laboratorium budaya, film, televisi, video (VCD, DVD), komputer dan internet.

Sumber belajar yang relatif beragam dan khas tersebut perlu dirawat dan dikelola secara baik dan profesional agar dapat memberikan kontribusi optimal dalam peningkatan mutu pembelajaran, seperti yang diungkapkan Majid (2009, p.171) bahwa sumber belajar hanya akan bermakna pada pembelajaran apabila sumber belajar diorganisir melalui satu rancangan yang memungkinkan seseorang memanfaatkannya sebagai sumber belajar. Ran- cangan tersebut dimungkinkan dalam bentuk unit-unit khusus yang didalamnya terdapat personel yang berkeahlian, berketerampilan dan berkompetensi dalam bidang pariwisata, teknologi informasi dan komunikasi, dan teknologi pembelajaran. Sehingga pengelolaan sumber belajar menjadi efektif dan efisien. Sistem pengelolaan yang baik secara tidak langsung akan berimplikasi positif terhadap efektivitas pemanfaatan sumber belajar.

Berdasarkan hasil observasi lapangan, nampaknya efektivitas pemanfaatan sumber belajar belum optimal. Pernyataan tersebut didasarkan pada hasil pengamatan bahwa pemanfaatan sumber belajar yang telah tersedia baik by design seperti laboratorium bahasa dan perpustakaan maupun sumber belajar yang by utilization seperti komputer dan internet (Gafur, 2010, p.4) belum dimanfaatkan secara optimal dalam pembelajaran oleh sebagian dosen dan mahasiswa. Kecenderungan yang ditemukan adalah sebagian dosen dan mahasiswa hanya memanfaatkan sebagian kecil dari sumber belajar yang ada seperti buku teks, handout, spidol dan papan tulis sebagai sumber belajar utama, selain dosen sebagai narasumber.

Dalam konteks teknologi pembelajaran, sumber belajar adalah pokok kajian yang tidak terpisahkan dalam lima kawasan teknologi pembelajaran yaitu, kawasan desain, pengembangan, pemanfaatan, pengelolaan dan evaluasi (Seels \& Richey, 1994, p.23). Oleh karena itu, agar mendapatkan informasi menyeluruh terkait dengan sumber belajar maka seharusnya pengkajian sumber belajar dilakukan secara komprehensif mencakup kelima kawasan dalam teknologi pembelajaran. Namun demikian, mengingat urgensi dan keterbatasan peneliti maka dalam penelitian ini difokuskan pada kawasan pengelolaan dan pemanfaatan.

Merujuk pada asumsi dan temuan tersebut maka penelitian ini ditujukan untuk melakukan kajian mendalam mengenai pola pengelolaan dan pemanfaatan sumber belajar dalam perspektif teknologi pembel- 
ajaran, khususnya di STP AMPTA Yogyakarta. Diharapkan melalui penelitian ini dapat diperoleh deskripsi lengkap mengenai pola pengelolaan dan pemanfaatan sumber belajar yang faktual dan empiris. Sehingga dapat digunakan sebagai acuan dalam penyelesaian masalah yang dihadapi dan sebagai bahan kajian dalam perbaikan mutu pembelajaran dan mutu pendidikan secara umum.

\section{Metode Penelitian}

Penelitian ini merupakan penelitian deskriptif. Penelitian ini ditujukan untuk membuat deskripsi mendalam tentang fenomena-fenomena atau keadaan yang terkait pengelolaan dan pemanfaatan sumber belajar di STP AMPTA Yogyakarta. Data yang diperoleh berupa kata-kata, kalimat-kalimat, dan dokumen-dokumen yang berelevansi dengan tujuan penelitian.

Objek penelitian tidak dimanipulasi atau diberi perlakuan tertentu, sehingga berada pada kondisi alami. Data dikumpulkan melalui wawancara mendalam, analisis dokumen dan pengamatan lapangan. Kemudian data tersebut dianalisis secara induktif. Lebih lanjut, peneliti tidak melakukan intervensi apapun. Peneliti bertindak sebagai instrumen utama penelitian dengan menggunakan instrumen bantu, alat tulis, alat dokumentasi dan alat perekam.

\section{Waktu dan Tempat Penelitian}

Penelitian ini dilaksanakan di STP AMPTA Yogyakarta. Lokasi tersebut dipilih karena merupakan salah satu sekolah tinggi pariwisata yang cukup besar di wilayah Jawa Tengah dan D.I. Yogyakarta. Selain itu, STP AMPTA Yogyakarta juga menjadi penyelenggara uji kompetensi untuk beberapa bidang ketrampilan dalam rumpun pendidikan pariwisata. Dengan demikian, STP AMPTA Yogyakarta dianggap memiliki sumber belajar yang relatif representatif. Waktu penelitian ini dilakukan pada bulan September-November 2013.

\section{Subjek Penelitian}

Subjek penelitian ini adalah ketua beserta pembantu ketua, dosen, staff administrasi dan mahasiswa. Subyek penelitian ditemui secara terpisah dan diberikan pertanyaan sesuai dengan kapasitasnya. Sedangkan objek penelitian ini adalah sumber belajar yang terdapat di STP AMPTA Yogyakarta.

\section{Teknik Pengumpulan Data}

Teknik pengumpulan data yang digunakan pada penelitian ini yaitu wawancara secara mendalam, observasi, dan kajian dokumen. Wawancara digunakan untuk memperoleh informasi dan penjelasan dari subjek penelitian terkait proses pengelolaan dan pemanfaatan sumber pembelajaran di STP AMPTA Yogyakarta. Wawancara dilakukan dengan menggunakan acuan prinsip pengelolaan dan pemanfaatan dalam perspektif teknologi pembelajaran dan dilakukan terhadap ketua, wakil ketua, staff administrasi, dosen dan mahasiswa STP AMPTA Yogyakarta.

Observasi yang dimaksud pada penelitian ini adalah observasi langsung terhadap subjek penelitian dan sumber belajar secara cermat dan objektif. Melalui observasi langsung, aktivitas pengelolaan dan pemanfaatan sumber belajar dapat teramati secara faktual. Data yang diperoleh dari observasi langsung digunakan sebagai penguji kebenaran data yang diperoleh dari wawancara dan pengkajian dokumen.

Kajian dokumen dilakukan dengan cara mempelajari berbagai data tertulis yang mendukung pelaksanaan pengelolaan dan pemanfaatan sumber belajar di STP AMPTA Yogyakarta. Kajian dokumen ini dilakukan untuk mencari titik temu antara data yang diperoleh melalui wawancara dengan data yang terhimpun dari dokumen-dokumen dan arsip lembaga yang berelevansi terhadap tujuan penelitian.

\section{Teknik Analisis Data}

Data yang diperoleh pada penelitian ini dianalisis menggunakan proses pe- 
nyederhanaan data ke dalam bentuk yang lebih sederhana untuk dibaca dan diinterpretasikan. Langkah-langkah analisis data pada penelitian ini mengadopsi model interaktif Miles \& Huberman dalam Sugiyono (2009, p.338) yaitu reduksi data, penyajian data, dan verifikasi data.

Reduksi data dilakukan dengan cara menyusun data dari lokasi penelitian dalam bentuk uraian laporan yang lengkap dan terinci. Data kemudian direduksi, dirangkum, dan kemudian dikelompokkan. Reduksi data dilakukan terus menerus selama proses penelitian berlangsung. Pada tahapan ini setelah data dikelompokkan kemudian disederhanakan, data yang tidak diperlukan dipisahkan agar memudahkan dalam penyajian, dan penarikan simpulan sementara.

Penyajian data dimaksudkan untuk mempermudah dalam melihat gambaran secara keseluruhan atau bagian-bagian tertentu dari data penelitian. Pada tahap ini dilakukan pengorganisasian data ke dalam bentuk bagan dan teks naratif. Data-data tersebut kemudian dipilah-pilah menurut kelompoknya dan disusun berdasarkan kategori yang ditetapkan untuk ditampilkan agar sesuai dengan permasalahan yang dihadapi, termasuk simpulan-simpulan sementara yang diperoleh pada tahap reduksi data.

Verifikasi data dilakukan secara terus menerus sepanjang proses penelitian dilakukan. Tahapan ini berakhir apabila data yang diperoleh sudah sampai pada titik jenuh dan dimungkinkan tidak akan terjadi perubahan simpulan yang signifikan. Simpulan yang diperoleh pada penelitian ini adalah deskripsi mendalam tentang pola pengelolaan dan pemanfaatan sumber belajar di STP AMPTA Yogyakarta

\section{Hasil Penelitian dan Pembahasan}

Berdasar pada aktivitas wawancara, pengamatan lapangan dan pengkajian dokumen ditemukan beragam data empiris yang mendeskripsikan secara rinci pola pengelolaan dan pemanfaatan sumber bel- ajar yang diterapkan di STP AMPTA Yogyakarta. Berikut pemaparan hasil penelitian yang disajikan secara deskriptif beserta analisis data yang didasarkan pada aktivitas pengumpulan data tersebut.

Sumber Belajar di STP AMPTA Yogyakarta

Melalui proses pengambilan data diketahui bahwa sumber belajar yang tersedia di STP AMPTA Yogyakarta dapat dikelompokkan dalam 6 kategori yaitu pesan, orang, bahan, teknik, alat dan lingkungan. Berikut adalah deskripsi tiaptiap kategori sumber belajar yang didasarkan pada temuan penelitian.

\section{Pesan}

Sumber belajar yang berupa pesan pada penelitian ini dibatasi pada kurikulum, silabus, dan RPP. Hal ini dimaksudkan agar kajian yang dilakukan dapat terfokus dan mendalam. Berdasarkan temuan pada dokumen kurikulum STP AMPTA Yogyakarta diketahui bahwa kurikulum yang dikembangkan oleh STP AMPTA memiliki karakteristik berbasis kompetensi dan bertendensi kebutuhan dunia pariwisata.

Penyusunan kurikulum yang berla$\mathrm{ku}$ di STP AMPTA Yogyakarta ditentukan dengan beban kredit untuk tiap-tiap jenjang. Untuk jenjang Diploma III, beban kredit yang harus ditempuh oleh mahasiwa berjumlah 116 SKS. Untuk jenjang Diploma IV mensyaratkan mahasiswa untuk menempuh 150 SKS untuk program Adiministrasi Hotel dan 152 SKS untuk Program Manajemen Bisnis Pariwisata. Untuk jenjang S1 yaitu program Pariwisata/Hospitality mensyaratkan mahasiswa menempuh 148 SKS.

Silabus dan RPP untuk tiap-tiap mata kuliah dikembangkan sendiri oleh dosen pengampu mata kuliah. Oleh karena dokumen tersebut disusun dan dikembangkan sendiri oleh tiap-tiap dosen, struktur dan pola penyusunannya cenderung berbeda. 
Orang

Sumber belajar dalam kategori orang pada penelitian ini dikelompokkan menjadi dua yaitu tenaga edukatif dan subjek didik atau mahasiswa. Dua kelompok tersebut dianggap dalam penelitian ini adalah sumber belajar dalam kategori orang yang memiliki peran aktif dalam pembelajaran.

Berdasarkan data yang diperoleh melalui kajian dokumen yang dimiliki STP AMPTA Yogyakarta diketahui bahwa jumlah tenaga edukatif di sekolah tinggi tersebut berjumlah 64 orang yang terdiri dari 42 dosen tetap dan 22 dosen tidak tetap. Dosen-dosen tersebut tersebar dalam 5 program studi. Rincian data dosen disajikan pada Tabel 1.

Tabel 1. Jumlah dan Jenjang Pendidikan Dosen

\begin{tabular}{lccccc}
\hline \multirow{2}{*}{\multicolumn{1}{c}{ Prodi }} & \multicolumn{3}{c}{ Jenjang } & \\
& Sendidikan & \multirow{2}{*}{$\Sigma$} & \\
\cline { 2 - 5 } & S1 & S2 & S3 & \\
\hline Per hotelan(D3) & 9 & 4 & - & 13 \\
Usaha Perjalanan Wisata (D3) & 3 & 4 & - & 7 \\
Administrasi Hotel (D4) & 1 & 5 & - & 6 \\
Manajemen Bisnis Perjalanan (D4) & 0 & 6 & - & 6 \\
Hospitality (S1) & 2 & 4 & - & 6 \\
Lintas Prodi* & 21 & 4 & 1 & 26 \\
\hline Jumlah & 43 & 20 & 1 & 64 \\
\hline *) Dosen Lintas Prodi adalah sebutan & yang \\
diberikan kepada dosen yang tidak memiliki \\
homebase prodi.
\end{tabular}

Berdasarkan data dosen tersebut, dapat diketahui bahwa sebagian besar dosen STP AMPTA Yogyakarta masih berpendidikan Sarjana Strata 1. Tercatat pada tabel di atas terdapat 43 dosen atau sekitar $60 \%$ memiliki kualifikasi pendidikan strata 1 , sedangkan dosen yang telah berpendidikan Strata 2 berjumlah kurang dari separuh jumlah keseluruhan dosen yaitu 20 dosen atau hanya $40 \%$. Berdasarkan data juga diketahui bahwa terdapat satu dosen lintas prodi yang telah berpendidikan S-3.
Selain klasifikasi dosen pada tabel di atas, STP AMPTA Yogyakarta juga menggunakan tenaga edukatif lainnya yang memiliki keahlian praktis terkait mata kuliah tertentu. Istilah yang digunakan adalah dosen tamu. Dosen tamu adalah seorang praktisi atau tenaga ahli yang keahliannya bersifat khusus dan tidak dimiliki oleh dosen pengampu mata kuliah. Misalnya dalam mata kuliah Pabean, Imigrasi \& Karantina pada Program Studi Usaha Perjalanan Wisata, apabila dosen pengampu mata kuliah tersebut merasa perlu memberikan tambahan informasi yang bersifat empiris maka dosen terkait mempunyai hak untuk mengundang dosen tamu yang memiliki keterlibatan secara langsung dengan mata kuliah tersebut misalnya pegawai imigrasi.

Sumber belajar dalam kategori orang berikutnya adalah mahasiswa. Mahasiswa memiliki peran penting dalam pembelajaran pada era sekarang ini. Peran mahasiswa tidak lagi sebagai objek didik yang bertugas menerima materi perkuliahan dari dosen, namun lebih dari itu mahasiswa memiliki posisi sentral dalam sebuah aktivitas pembelajaran atau yang lebih dikenal dengan istilah student centered. Dalam pengertian tersebut, mahasiswa bukan lagi menjadi objek didik semata melainkan berperan sebagai subjek didik yang memiliki daya untuk belajar. Oleh karena itu, peran aktif mahasiswa dalam pembelajaran merupakan bagian dari sumber belajar yang mendukung tercapainya tujuan pembelajaran.

Kondisi mahasiswa STP AMPTA Yogyakarta dari tahun ke tahun selalu mengalami perubahan. Baik dalam hal jumlah maupun mutu masukan dan keluaran/lulusan. Persaingan antar perguruan tinggi pariwisata diduga menjadi salah satu alasan fluktuasi kuantitas dan kualitas mahasiswa STP AMPTA Yogyakarta. Berikut adalah tabel jumlah mahasiswa STP AMPTA Yogyakarta dalam rentang lima tahun terakhir disajikan pada Tabel 2. 
Tabel 2. Jumlah Mahasiswa dalam Lima Tahun Terakhir di STP AMPTA Yogyakarta

\begin{tabular}{lccccc}
\hline \multirow{2}{*}{ Prodi } & \multicolumn{5}{c}{ Tahun Ajaran } \\
\cline { 2 - 6 } & $2009 / 2010$ & $2010 / 2011$ & $2011 / 2012$ & $2012 / 2013$ & $2013 / 2014^{*}$ \\
\hline Perhotelan & 329 & 366 & 353 & 618 & 315 \\
Usaha Perjalanan Wisata & 66 & 59 & 47 & 86 & 41 \\
Administrasi Hotel & 164 & 169 & 185 & 431 & 224 \\
Manajemen Bisnis Perjalanan & 97 & 102 & 105 & 276 & 123 \\
Hospitality & 22 & 64 & 127 & 482 & 296 \\
\hline Jumlah & 678 & 760 & 817 & 1893 & 999 \\
\hline
\end{tabular}

Tabel 2 menunjukkan jumlah mahasiswa aktif dalam lima tahun ajaran terakhir yaitu tahun ajaran 2009/2010, 2010/2011，2011/2012, 2012/2013 dan 2013/2014. Data tersebut adalah data yang didasarkan pada jumlah mahasiswa aktif pada satu tahun ajaran yang terdiri atas semester ganjil dan genap, kecuali tahun ajaran 2013/2014. Merujuk pada data tersebut tampak bahwa terjadi peningkatan jumlah mahasiswa dari tahun ke tahun. Lompatan jumlah mahasiswa terjadi pada tahun ajaran 2012/2013, yaitu berjumlah 1893 mahasiswa dari 817 jumlah mahasiswa pada tahun ajaran sebelumnya.

Data di atas juga menunjukan bahwa program studi yang paling banyak memperoleh mahasiswa adalah Prodi Perhotelan, sedangkan prodi yang memiliki tren positif adalah Prodi Hospitality. Meskipun Hospitality merupakan prodi baru namun tampaknya peluang kerja yang ditawarkan cukup menjanjikan, sehingga peminat prodi tersebut semakin meningkat dari tahun ke tahun.

\section{Bahan}

Bahan sebagai salah satu sumber belajar memiliki keterkaitan sangat erat dengan sumber belajar lainnya. Jika sumber belajar dalam kategori bahan didefinisikan sebagai segala sesuatu yang mengandung pesan yang dibuat oleh orang (dosen) dan disajikan melalui alat, kehadiran bahan akan mempengaruhi dan dipengaruhi oleh pesan, orang dan alat. Dengan kata lain, kahadiran satu sumber belajar pasti mem- pengaruhi atau dipengaruhi oleh sumber belajar lainnya.

Berdasarkan data yang diperoleh dalam proses observasi diketahui bahwa sumber belajar dalam kategori bahan yang ditemukan di STP AMPTA Yogyakarta cukup beragam. Berikut adalah kategorisasi bahan beserta media penyajinya yang disajikan pada Tabel 3.

Tabel 3. Sumber Belajar dalam kategori Bahan

\begin{tabular}{|c|c|}
\hline Jenis bahan & Alat/medium penyaji \\
\hline Transparansi & Over Head Projector \\
\hline Slide & $\begin{array}{l}\text { Projector-Computer, } \\
\text { laptop, pad, tablet PC. }\end{array}$ \\
\hline Web-Blog & PC, smartphone, tablet PC \\
\hline $\begin{array}{l}\text { Bahan Cetak (Buku, } \\
\text { Diktat, majalah) }\end{array}$ & Perpustakaan \\
\hline Arca & Taman kampus \\
\hline $\begin{array}{l}\text { Film/jenis audio-vidio } \\
\text { lainnya }\end{array}$ & Projector \\
\hline
\end{tabular}

Data yang terangkum pada tabel di atas menunjukkan bahwa sumber belajar dalam kategori bahan yang ditemukan di STP AMPTA Yogyakarta dapat diidentifikasi menjadi enam jenis yaitu transparansi, slide, web-blog, bahan cetak, arca dan film (audio-visual).

Alat

Sumber belajar dalam kategori alat yang tersedia dan dapat digunakan di STP AMPTA Yogyakarta cukup beragam dan bersifat tematik. Keberagaman tematis tersebut menjadi sebuah keniscayaan karena 
STP AMPTA menyelenggarakan pendidikan vokasi yang menuntut tersedianya peralatan yang didesain khusus atau setidaknya disesuaikan untuk menunjang pendidikan pariwisata, dalam konteks ini adalah pendidikan perhotelan dan perjalanan wisata serta Ilmu Pariwisata (Hospitality).

Berikut adalah tabel peralatan yang tersedia dan dapat digunakan sebagai penyampai pesan dalam pembelajaran di Sekolah Tinggi Pariwisata AMPTA Yogyakarta.

Tabel 4. Sumber Belajar dalam Kategori

\begin{tabular}{lcc}
\multicolumn{3}{c}{ Alat } \\
\hline \multicolumn{1}{c}{ Nama Alat } & $\begin{array}{c}\text { Jumlah } \\
\text { unit }\end{array}$ & Kondisi \\
\hline Over Head Projector & 15 & Baik \\
Projector & 14 & Baik \\
Personal Computer & 51 & Baik \\
White Board Set & 14 & Baik \\
KirchenE Pastry Set & 1 & Baik \\
Bar E Restoran Set & 1 & Baik \\
Mocked Up Room Set & 2 & Baik \\
Reception Set & 1 & Baik \\
Tour ETravel Agency Set & 1 & Baik \\
\hline
\end{tabular}

Merujuk pada temuan data tersebut, diketahui bahwa sebagian besar alatalat pembelajaran yang digunakan memiliki kekhasan dan bersifat tematis. Sebagian alat-alat tersebut secara khusus didesain untuk kepentingan pembelajaran mata kuliah tertentu dan sebagian alat-alat yang lain diadopsi dan diadaptasi dari fungsi aslinya. Dengan demikian, peralatan yang digunakan sebagai sumber belajar di STP AMPTA Yogyakarta menggunakan prinsip alat yang by design dan by utilization

\section{Teknik}

Melalui wawancara yang dilakukan kepada mahasiswa dan dosen STP AMPTA Yogyakarta, diketahui bahwa dosen dalam penyampaian materi perkuliahan menggunakan pendekatan mengajar yang beragam. Beberapa teknik mengajar yang teridentifikasi digunakan dalam perkuliahan adalah ceramah, role play, tanya jawab, demonstrasi, dan penugasan.
Dalam petikan wawancara tergali informasi bahwa teknik mengajar yang berpusat pada dosen tidak disukai mahasiswa dan cenderung tidak efektif. Oleh karena itu, pada era pendidikan modern sekarang ini, pembelajaran yang berpusat pada subjek didik atau mahasiswa adalah sebuah keniscayaan. Jadi teknik mengajar apapun yang digunakan oleh dosen harus mengedepankan keaktifan mahasiswa dalam penemuan dan pendalaman materimateri perkuliahan.

\section{Lingkungan}

STP AMPTA Yogyakarta merupakan perguruan tinggi pariwisata yang memiliki lingkungan belajar yang cukup kondusif. Letak geografis yang berada tidak dipinggir jalan raya menjadikan pembelajaran tidak terganggu oleh suara bising lalu lalang kendaraan bermotor. Selain itu, STP AMPTA Yogyakarta juga didukung dengan fasilitas belajar yang relatif representatif dan lengkap. Berikut adalah tabel sumber belajar dalam kategori lingkungan dalam bentuk ruang dan laboratorium.

Tabel 5. Sumber Belajar dalam Kategori Lingkungan

\begin{tabular}{lccc}
\hline \multirow{2}{*}{ Nama } & \multicolumn{2}{c}{ Keterangan } & \\
\cline { 2 - 3 } & Satuan & $\begin{array}{c}\text { Luas } \\
(\mathrm{m} 2)\end{array}$ & \\
\hline Ruang Kelas & 11 & 1040 & Baik \\
Perpustakaan & 1 & 200 & Baik \\
Lab. Komputer & 1 & 120 & Baik \\
Lab. Bahasa & 1 & 72 & Baik \\
Lab. Front Office & 1 & 64 & Baik \\
Lab. Housekeeping & 2 & 96 & Baik \\
Lab. Laundry & 1 & 20 & Baik \\
Lab. Pastry & 1 & 40 & Baik \\
Lab. Food Product/Kitchen & 1 & 144 & Baik \\
Lab. Bar and Restaurant & 1 & 72 & Baik \\
Lab. Travel Agent & 1 & 15 & Baik \\
Lab. Seni Budaya & 1 & 80 & Baik \\
\hline
\end{tabular}

Melalui data pada Tabel 5 dapat diketahui bahwa STP AMPTA Yogyakarta memiliki 11 ruang kelas, 1 perpustakaan dan 9 laboratorium tematik yang dengan demikian dapat dikatakan STP AMPTA 
Yogyakarta memiliki lingkungan belajar yang mendukung proses perkuliahan.

Pengelolaan Sumber Belajar

Berdasar pada observasi dan wawancara diketahui bahwa tidak terdapat unit khusus yang dibentuk untuk mengelola dan bertanggung jawab terhadap sumber belajar yang tersedia di STP AMPTA Yogyakarta. Oleh karena itu, fungsi-fungsi pengelolaan sumber belajar yang terdiri atas perencanaan, pengorganisasian, pengkoordinasian dan pengawasan, dilakukan oleh beberapa personel dalam bagian yang terpisah-pisah namun secara relatif memiliki keahlian dan kompetensi yang dibutuhkan untuk mengelola setiap kategori sumber belajar.

\section{Perencanaan Sumber Belajar}

Selama proses pengkajian dokumen ditemukan tiga dokumen yang terkait dengan perencanaan yaitu Rencana Operasional Tahunan (ROT), Rencana Strategis (Renstra) 2010-2015, dan Rencana Induk Pengembangan Pendidikan (RIP) 20102020. Ketiga dokumen tersebut adalah acuan pengelolaan pendidikan di STP AMPTA Yogyakarta dalam kurun waktu satu, lima dan sepuluh tahun sejak dokumen tersebut disusun dah disahkan. Melalui dokumendokumen tersebut diketahui bahwa perencanaan tersebut disusun berdasarkan kondisi internal dan ekstenal lembaga dengan menggunakan analisa SWOT sebagai pijakan teoretik. Kondisi internal yang dimaksud adalah kondisi yang mengindikasikan kekuatan dan kelemahan. Sedangkan kondisi eksternal adalah kondisi yang mengindikasikan peluang dan tantangan yang akan dihadapi oleh STP AMPTA pada kisaran kurun waktu yang telah ditentukan yaitu satu, lima maupun sepuluh tahun kedepan. Dengan demikian, dalam kurun waktu 10 tahun, arah kerja dan kebijakan lembaga sudah terstruktur.

Penyusunan perencanaan tersebut didasarkan pada perubahan-perubahan lingkungan dan kebutuhan untuk menja- min eksistensi dan mutu perguruan tinggi. Dalam dokumen RIP dijelaskan empat dasar pemikiran penyusunan perencanaan yaitu: (1) perubahan tuntutan masyarakat mengenai kualitas pendidikan dan lulusan; (2) perkembangan information and communication (ICT) dan pengetahuan yang perlu dipenuhi dan dikuasai untuk kepentingan proses pendidikan, penelitian dan pengabdian pada masyarakat; (3) perubahan lingkungan pendidikan, persaingan antar perguruan tinggi, Undang-Undang tentang pendidikan dan peraturan pemerintah, dan (4) perubahan lingkungan internal khususnya pada kualitas tenaga akademik dan tenaga administratif.

Perencanaan yang disusun oleh STP AMPTA bersifat komprehensif dan luas, di dalamnya termuat semua aspek pengelolaan, sehingga diperlukan koordinasi untuk menerjemahkan dan merealisasikan grand design perencanaan yang telah disusun agar sesuai dengan kebutuhan. Termasuk di dalam perencanaan tersebut adalah perencanaan terkait dengan pengadaan, pengembangan dan pemutakhiran sumber belajar.

\section{Pengorganisasian Sumber Belajar}

Berdasarkan pengkajian dokumen diketahui bahwa tidak terdapat struktur formal yang secara langsung dan eksplisit menunjuk kepada unit atau personel tertentu untuk mengelola sumber belajar. Di dalam penjelasan tugas pokok dan fungsi (tupoksi) personel dan pengurus harian STP AMPTA Yogyakarta diketahui bahwa pengelolaan sumber belajar tidak diterangkan dalam tupoksi salah satu personel secara spesifik, bahkan istilah sumber belajar tidak dimunculkan dalam dokumen tersebut.

Merujuk pada dokumen tersebut diketahui bahwa tanggungjawab pengelolaan sumber belajar terbagi pada beberapa personel yaitu, pembantu ketua I beserta jajaran dibawahnya; ketua jurusan, bagian dikjar dan unit pelaksana teknis (bagian laboratorium dan perpustakaan), 
pembantu ketua II beserta beberapa jajaran dibawahnya; bagian keuangan, personalia, dan bagian rumah tangga dan pemeliharaan.

\section{Pengkoordinasian Sumber Belajar}

Proses pengkoordinasian yang di dalamnya termasuk pengaturan, penyatuan, penyerasian, pengintegrasian semua kegiatan yang berkaitan dengan sumber belajar di STP AMPTA Yogyakarta dilakukan oleh pembantu ketua I beserta jajarannya yaitu, ketua jurusan dan bagian yang berada dibawahnya (sekretaris jurusan). Meskipun demikian, pada tataran operasional praktis fungsi koordinasi menjadi tanggungjawab ketua jurusan. Masing-masing ketua jurusan diberikan kewenanangan untuk mengatur sumber belajar sebagai bagian dari pengelolaan jurusan.

Dalam proses wawancara dengan pembantu ketua I diperoleh informasi bahwa ketua jurusan memiliki peran sentral dalam pengkoordinasian sumber belajar. Sebagai seorang koordinator, masing-masing ketua jurusan dituntut mengetahui kondisi sumber belajar yang ada dan dapat dimanfaatkan dalam proses perkuliahan pada lingkup jurusan yang dipimpinnya.

\section{Pengawasan Sumber Belajar}

Pada fase ini diketahui tentang efektivitas dan efisiensi penggunaan sumber belajar serta tindakan lanjutan yang mungkin diambil sebagai langkah solutif dalam setiap persoalan yang muncul. Pengawasan sumber belajar di STP AMPTA Yogyakarta tidak dilakukan secara terpadu melainkan dilakukan oleh unit-unit dan personel yang secara langsung bersentuhan dengan tiap-tiap jenis sumber belajar. Hal ini adalah konsekuensi logis yang disebabkan tidak dibentuknya unit khusus pengelola sumber belajar. Berdasar pada hasil wawancara dengan pembantu ketua I diperoleh informasi bahwa penanggung jawab pengawasan sumber belajar secara umum adalah ketua jurusan.
Dengan merujuk pada pernyataan tersebut maka terdapat 3 penanggung jawab sumber belajar di STP AMPTA Yogyakarta yaitu Ketua Jurusan Perhotelan, Usaha Perjalanan Wisata dan Hospitality. Dalam menjalankan fungsi pengawasan tersebut, ketua jurusan dibantu oleh bagian rumah tangga. Bagian tersebut bertugas melakukan perawatan terhadap lingkungan belajar beserta alat-alat pembelajaran.

\section{Pemanfaatan Sumber Belajar}

Pemanfaatan sumber belajar dalam penelitian ini dikaji menggunakan perspektif teknologi pembelajaran. Dalam penelitian ini aspek pemanfaatan sumber belajar dirumuskan sebagai berikut: (1) pemanfaatan sumber belajar sebagai media pembelajaran; (2) difusi inovasi sumber belajar; (3) implementasi dan pelembagaan sumber belajar; (4) kebijakan dan regulasi yang berkaitan dengan sumber belajar. Pengkajian pemanfaatan sumber belajar pada penelitian ini dilakukan secara menyeluruh kepada mahasiswa, dosen, dan semua pihak yang terlibat dalam pemanfaatan sumber belajar.

\section{Pemanfaatan Sumber Belajar sebagai Media Pembelajaran}

Berdasarkan hasil observasi, pengkajian dokumen, dan wawancara diketahui jenis sumber belajar yang tersedia di STP AMPTA Yogyakarta sudah cukup representatif untuk mendukung proses perkuliahan. Demikian juga dengan rasio perbandingan jumlah ketersediaan media dengan pengguna (mahasiswa dan dosen). Kondisi tersebut berimplikasi positif pada efektivitas dan ketercapaian tujuan perkuliahan.

Meskipun ketersediaan dan jenis sumber belajar di STP AMPTA sudah baik namun ada beberapa temuan yang menjadi catatan, antara lain adalah pemanfaatan media pembelajaran berbasis komputer. Berdasarkan data yang diperoleh diketahui bahwa media tersebut telah diaplikasikan 
di semua ruang perkuliahan sejak tahun 2012. Media tersebut terdiri atas 1 unit komputer Compaq i3-3, $3 \mathrm{GHz}$, monitor Compaq LCD 20" dan 1 unit proyektor Infocus 2.700 lumen. Walaupun perangkat media berbasis komputer tersebut memiliki spesifikasi tergolong tinggi dan memiliki kecepatan yang tergolong cepat, namun pemanfaatan dalam proses pembelajaran baik oleh dosen maupun mahasiswa cenderung tidak optimal. Kondisi tersebut disebabkan karena tidak dilakukan perawatan secara berkala, baik pada software maupun hardware yang terintegrasi pada media tersebut. Akibat tidak dilakukan perawatan berkala adalah beberapa komputer telah terserang virus komputer seperti virus trojan. Terjangkitnya komputer oleh virus disebabkan karena aktivitas perpindahan data melalui flash disk atau penyimpan data lainnya yang dilakukan oleh dosen maupun mahasiswa dalam proses perkuliahan. Kondisi tersebut secara tidak langsung mempengaruhi efektivitas pemanfaatan komputer dalam perkuliahan.

Selain pemanfaatan komputer di semua kelas teori yang cenderung tidak optimal oleh dosen dan mahasiswa, diperoleh pula informasi tentang pemanfaatan beberapa laboratorium yang kurang optimal dalam memberikan manfaat kepada mahasiswa. Laboratorium tersebut adalah kitchen dan pastry. Informasi tersebut diperoleh melalui wawancara dengan mahasiswa program studi perhotelan yang secara langsung praktik pada laboratorium tersebut.

Dalam petikan wawancara diperoleh informasi bahwa mahasiswa tidak dapat memanfaatkan laboratorim secara optimal. Responden menyatakan model perkuliahan praktik yang dilakukan bersama-sama (satu kelas) tidak atau kurang efektif. Kondisi tersebut pada dasarnya dapat dipahami karena jumlah mahasiswa peserta mata kuliah tersebut sangat banyak. Mahasiswa Prodi Perhotelan dan $\mathrm{ADH}$ wajib mengikuti mata kuliah tersebut, sehingga intensitas mahasiswa dalam berinteraksi dengan alat, bahan, dan teknik pengolahan makanan/kue menjadi terbatas. Namun demikian, berdasarkan pengkajian dokumen diketahui bahwa STP AMPTA Yogyakarta telah mensikapi persoalan tersebut dengan memberikan kesempatan kepada mahasiswa untuk mengikuti ekstrakurikuler culinary club. Culinary club merupakan kegiatan kemahasiswaan, di bawah bimbingan dosen mata kuliah pengolahan makanan/kue. Melalui kegiatan tersebut diharapkan interaksi terhadap alat, bahan dan teknik pengolahan makanan dapat dilakukan dengan lebih efektif.

Merujuk pada penjelasan sebelumnya, diketahui bahwa sumber belajar yang tersedia di STP AMPTA sudah dimanfaatkan oleh dosen dan mahasiswa untuk kepentingan pembelajaran, namun belum secara optimal. Oleh karena itu, perlu dilakukan pengkajian pola pengelolaan sumber belajar, sehingga sumber belajar yang telah tersedia dapat dimanfaatkan optimal untuk kepentingan pencapaian tujuan pembelajaran yang telah ditetapkan.

Difusi Inovasi Sumber Belajar

Berdasar pada proses pengkajian dokumen, pengamatan langsung pada objek-objek kajian dan wawancara dengan beberapa stakeholder STP AMPTA Yogyakarta didapatkan informasi tentang bagaimana difusi inovasi dilakukan. Dalam tiga tahun terakhir STP AMPTA telah melakukan beberapa inovasi strategis terkait dengan kelengkapan dan ketersediaan sumber belajar. Beberapa item, unit dan sistem baru telah diaplikasikan guna kepentingan pembaruan dan perubahan sebagai jawaban dari perkembangan zaman. Inovasiinovasi yang terindetifikasi antara lain pemanfaatan media berbasis komputer dan internet dalam proses perkuliahan menggantikan teknologi lama seperti OHP, upgrade teknologi yang digunakan pada laboratorium bahasa, pengadaan peralatanperalatan modern untuk melengkapi laboratorium-laboratorium, dan penggantian sistem manual pada pengelolaan perpustakaan menjadi terkomputerisasi dengan 
menggunakan sistem operasi Online Public Access Catalog (OPAC) yang juga digunakan di beberapa perpustakaan perguruan tinggi lainnya.

Inovasi-inovasi yang dilakukan tersebut disebarluaskan melalui berberapa saluran atau media. Penyebarluasan inovasi merupakan tahapan penting sebelum produk inovasi dapat digunakan dan memberi manfaat optimal dalam pencapaian tujuan pembelajaran di STP AMPTA Yogyakarta. Saluran-saluran penyebaran inovasi yang dilakukan antara lain adalah website STP AMPTA Yogyakarta yang beralamat di www.ampta.ac.id. Pada website tersebut selain termuat hampir semua informasi tentang STP AMPTA Yogyakarta, yang dapat diakses oleh publik, juga digunakan sebagai media penyebaran inovasi-inovasi yang dilakukan di STP AMPTA Yogyakarta. Penyebaran inovasi melalui website dapat dilihat pada salah satu halaman pada website tersebut yang menjelaskan tentang telah dilengkapinya semua ruang kuliah dengan multimedia berbasis komputer dan internet. Selain website, diketahui pula bahwa proses penyebaran inovasi dilakukan melalui program-program koordinasi, sosialisasi, workshop atau pelatihan terkait dengan inovasi yang dilakukan. Sasaran program tersebut adalah dosen, mahasiswa dan semua pihak yang terkait dengan penggunaan produk inovasi tertentu.

Beberapa program yang dilakukan untuk tujuan difusi inovasi yang termati pada penelitian ini adalah (1) sosialisasi pemanfaataan laboratorium bahasa setelah dilakukan renovasi fisik dan sistem; (2) sosialisasi prosedur penulisan jurnal ilmiah secara online; dan (3) pelatihan pemanfaatan multimedia pembelajaran berbasis komputer dan internet. Program-program tersebut, menurut Puket I adalah agenda rutin yang harus dilakukan ketika ada pembaruan atau inovasi tertentu yang melibatkan dosen, mahasiswa, dan atau pihak-pihak tertentu.

Berdasar pada temuan-temuan penelitian dapat diikhtisarkan bahwa proses difusi inovasi telah berjalan dengan relatif baik. Proses difusi inovasi yang telah dijelaskan pada paragraf-paragraf sebelumnya merupakan langkah awal yang dilakukan sebelum suatu produk inovasi dapat diimplementasikan, digunakan secara masif dan dilembagakan di STP AMPTA Yogyakarta.

Implementasi dan Pelembagaan Sumber Belajar

Proses implementasi dan pelembagaan pada prinsipnya adalah dua proses yang berurutan. Sebelum proses pelembagaan terhadap suatu produk inovasi tertentu dilakukan maka proses implementasi harus lebih dulu dilakukan. Studi yang dilakukan di STP AMPTA Yogyakarta terkait dengan proses implementasi diketahui bahwa proses implementasi dan pelembagaan sudah berjalan dengan relatif baik. Proses implementasi yang teramati adalah proses penggunaan media pembelajaran berbasis TIK, khususnya penggunaan power point dan web-blog pembelajaran dalam proses perkuliahan. Pada awalnya, pemanfaatan dua media berbasis TIK tersebut, untuk kepentingan perkuliahan, tidak dapat diterima secara langsung oleh semua dosen. Ditengarai pada awal pengenalan TIK di STP AMPTA, sebagian besar dosen masih menggunakan OHP sebagai penyaji materi kuliah. Hal ini disebabkan literasi dosen terhadap TIK dan aplikasinya dalam pembelajaran sangat beragam dan cenderung masih rendah. Penolakan dan keluhan pada umumnya diungkapkan oleh para dosen senior yang bidang keilmuannya tidak secara langsung bersentuhan dengan TIK.

Dalam pada itu, untuk menyikapi kondisi tersebut, proses implementasi perlu dilakukan sebelum sebuah produk inovasi dapat secara massif digunakan dan dilembagakan. Proses implementasi di STP AMPTA dilaksanakan dengan beberapa cara dan tahapan. Berdasarkan hasil wawancara dengan pembantu ketua I diperoleh informasi bahwa proses implementasi didahului dengan pelaksanan workshop 
atau pelatihan yang berkaitan dengan produk inovasi yang akan digunakandalam konteks ini adalah Power Point dan web-blog. Workshop dan pelatihan tersebut dimaksudkan untuk mengenalkan dan melatih dosen atau siapapun yang terkait dengan pemanfaatan produk inovasi yang akan digunakan. Tahap berikutnya, setelah workshop dan pelatihan dilakukan, dosendosen dihimbau mengimplementasikan media Power Point sebagai variasi penyajian materi kuliah. Pada tahap ini dilakukan monitoring terhadap efektivitas pemanfaatan Power Point dan web-blog pembelajaran. Bentuk monitoring yang dilakukan adalah dengan cara pengumpulan informasi dari mahasiswa yang dilakukan oleh Ketua Jurusan beserta jajarannya. Ketua jurusan Hospitality menyatakan bahwa sebagian besar Mahasiswa lebih menyukai dosen yang menggunakan Power Point daripada sekedar menggunakan white board atau OHP.

Melalui tahapan tersebut, semua dosen STP AMPTA Yogyakarta secara bertahap dapat memanfaatkan media berbasis komputer tersebut dengan baik. Dengan kalimat lain, proses implementasi berlangsung dengan baik. Dalam kondisi semua dosen sudah dapat mengintegrasikan TIK dalam perkuliahan maka proses selanjutnya-yaitu pelembagaan, dapat dilakukan. Di STP AMPTA Yogyakarta, pemanfaatan TIK telah menjadi bagian yang tidak dipisahkan. Hal ini menunjukkan bahwa pemanfaatan TIK sudah melembaga dan secara massif digunakan di lingkungan STP AMPTA Yogyakarta.

Model implementasi tersebut juga dilakukan pada semua bentuk inovasi yang diterapkan dan dilembagakan di STP AMPTA Yogyakarta, sehingga tidak terbatas pada salah satu sumber belajar tertentu.

\section{Kebijakan dan Regulasi Sumber Belajar}

Kebijakan dan Regulasi yang diterapkan di STP AMPTA Yogyakarta pada dasarnya sudah mencerminkan sistem pendidikan di perguruan tinggi yang cukup baik. Melalui pengkajian dokumen diperoleh informasi bahwa kebijakan dan regulasi telah dibuat dengan mempertimbangkan segala aspek dan bersifat visioner. Hal tersebut tertuang secara rinci pada dokumen rencana operasional tahunan, rencana strategis 2010-2015, dan rencana induk pengembangan pendidikan 20102020 STP AMPTA Yogyakarta. Namun demikian kebijakan dan regulasi yang secara spesifik menunjuk pada pengelolaan dan pemanfaatan sumber belajar tidak tercantumkan secara spesifik, bahkan istilah sumber belajar tidak dapat ditemukan pada semua dokumen kebijakan dan regulasi lembaga.

Meskipun tidak ditemukan dokumen yang secara spesifik mengatur sumber belajar, namun pada proses observasi dan wawancara diperoleh informasi terkait produk kebijakan dan aturan yang terkait dengan sumber belajar yaitu: (1) peraturan mengenai keharusan Dosen STP AMPTA Yogyakarta minimal berpendidikan magister atau master; (2) keharusan membuat diktat kuliah, rencana persiapan pembelajaran dan kontrak kuliah bagi semua dosen; (3) pemanfaatan multimedia dalam perkuliahan.

Merujuk pada penjelasan pada paragraf sebelumnya dapat dikatakan bahwa kebijakan dan regulasi yang terdapat di STP AMPTA belum secara ekspilsit menyentuh semua aspek sumber belajar. Pada kondisi tersebut, implikasi kebijakan dan regulasi terkait sumber belajar, baik dalam hal pemanfaatan media, difusi inovasi maupun implementasi dan pelembagaan belum optimal untuk peningkatan kualitas pembelajaran.

\section{Simpulan dan Saran}

Simpulan

Pengelolaan sumber belajar di STP AMPTA Yogyakarta terdiri atas fungsifungsi pengelolaan yaitu sebagai berikut.

Pertama, Perencanaan sumber belajar sudah dilakukan dengan melalui mekanisme Rencana strategis (Renstra), Ren- 
cana Induk Pengembangan (RIP), dan Rencana Operasional Tahunan (ROT). Kedua, Pengorganisasian sumber belajar di STP AMPTA Yogyakarta belum terbentuk. Dalam proses penelitian tidak ditemukan struktur organisasi yang merujuk pada pengorganisasian sumber belajar. Selain itu, tidak ditemukan pula unit yang secara khusus bertanggungjwab terhadap sumber belajar. Ketiga, Pengkoordinasian sumber belajar dilakukan oleh ketua jurusan dibantu oleh bagian rumah tangga. Ketua jurusan berkoordinasi dengan dosen ahli, tenaga ahli dan penanggungjawab laboratorium untuk memperoleh informasi berkaitan dengan kondisi sumber belajar. Keempat, Pengawasan sumber belajar menjadi tanggungjawab ketua jurusan dibantu oleh bagian pendidikan dan pengajaran dan bagian rumah tangga.

Pemanfaatan sumber belajar di STP AMPTA Yogyakarta mencakup empat dimensi berikut. Pertama, sumber belajar yang tersedia beragam dan disesuaikan dengan program studi yang diselenggarakan. Secara umum media yang tersedia sudah dimanfaatkan untuk kepentingan pencapaian tujuan pembelajaran. Namun demikian, potensi media yang berbasis TIK diketahui belum dimanfaatkan secara optimal. Hal ini disebabkan karena literasi dosen terhadap pemanfaatan TIK dalam pembelajaran masih relatif kurang. Kedua, difusi inovasi dilakukan melalui dua saluran yaitu saluran internal dan saluran eksternal. Saluran internal dilakukan dengan mengadakan rapat-rapat, sosialisasi, pelatihan dan workshop. Sedangkan saluran eksternal dilakukan melalui media massa baik media cetak maupun elektronik dan internet. Ketiga, implementasi dan pelembagaan sumber belajar di STP AMPTA Yogyakarta sudah dilakukan. Mekanisme implementasi didahului dengan pelaksanaan workshop atau pelatihan yang berkaitan dengan produk inovasi tertentu, apabila produk inovasi telah dapat digunakan secara massif kemudian diikuti dengan proses pelembagaan. Keempat, kebijakan dan regulasi, yang berkaitan dengan sum- ber belajar, belum secara spesifik menunjuk pada pengelolaan dan pemanfaatan sumber belajar.

Saran

Perlu dibentuk unit yang secara khusus bertanggungjawab terhadap pengelolaan sumber belajar. Unit khusus tersebut dapat berbentuk Pusat Sumber Belajar (PSB). Unit tersebut dapat berperan sebagai pengelola sistem pengelolaan yang terpadu dan terorganisir untuk merencanakan, mengembangkan, menyediakan, mengawasi dan mengevaluasi pemanfaatan sumber belajar dalam fungsinya sebagai pendukung proses pembelajaran. Melalui pembentukan unit tersebut diharapkan sumber belajar dapat lebih mudah diakses dan dimanfaatkan secara optimal oleh semua pihak terkait. Selain itu, dapat juga dilakukan pengawasan dan evaluasi terhadap efektifitas sumber belajar. Pembentukan PSB di STP AMPTA Yogyakarta disarankan melibatkan personel yang menguasai pengelolaan sumber belajar baik secara praktik maupun teoretik, sehingga PSB yang dibentuk dapat berfungsi optimal untuk mendukung tujuan pembelajaran.

Perlu dilakukan evaluasi secara periodik terhadap pemanfaatan sumber belajar, sehingga dapat diketahui efektifitas sumber belajr dalam mendukung tujuan akademis. Kemudian dapat dilakukan tindakan lanjutan apabila ditemukan sumber belajar yang tidak atau kurang efektif dalam mendukung tujuan akademis.

Program sosialisasi, pelatihan dan workshop terkait dengan pemanfaatan sumber belajar-terutama media berbasis TIK perlu lebih digiatkan baik dalam aspek kuantitas maupun kualitasnya. Program tersebut sebaiknya ditujukan untuk semua dosen baik dosen tetap maupun dosen tidak tetap dan diselenggarakan secara berkesinambungan. Dengan demikian, semua dosen akan dapat mengeksplorasi dan mengintegrasikan TIK dalam perkuliahan, sehingga secara bertahap TIK yang tesedia dapat dimanfaatkan secara optimal untuk peningkatan kualitas pembelajaran. 
Perspektif teoretik teknologi pembelajaran dapat digunakan sebagai alternatif dalam pengelolaan sumber belajar.

\section{Daftar Pustaka}

AECT Task Force. (1977). The definition of educational technology. Washington: AECT.

Depdiknas. (2005). Undang-undang ri nomor 14, tahun 2005, tentang guru dan dosen.

Depdiknas. (2005). Undang-undang ri nomor 19, tahun 2005, tentang standar nasional pendidikan.

Gafur, A. (2010). Pengelolaan sumber belajar. Yogyakarta: PPs UNY.
Januszwenski, A., \& Molenda, M. (Eds.). (2008). Educational technology: a definition with commentary. New York: Lawrence Erlbaum Associates

Kemdiknas. (2012). Undang-undang RI nomor 12, tahun 2012, tentang pendidikan tinggi.

Majid, A. (2009). Perencanaan pembelajaran. Bandung: PT. Remaja Rosadakarya.

Seels, B. \& Rita C. Richey. (1994). Instructional technology. Washington: AECT.

Sugiyono. (2009). Metode penelitian kualitatif: pendekatan kuantitatif, kualitatif, dan $r \mathcal{E}$. Bandung: PT. Alfabeta. 